\title{
Muslim Identity, Bengali Nationalism: An Analysis on Nationalism in Bangladesh
}

\author{
A. B. M. Nurul Absar \\ Lecturer in Islamic History and Culture, Centre for University Requirement Courses \\ International Islamic University Chittagong \\ Email:nurul.absar26@yahoo.com, Cell no: 0088-01818736333
}

Doi:10.5901/ajis.2014.v3n1p439

\begin{abstract}
When East Pakistan1 broke away from Pakistan to become the independent and sovereign nation of Bangladesh in 1971after nine month long war of independent against west Pakistan, many observers believed that South Asia was irrevocably on its route to a secular nationalism beyond religious 'tribalism'2 and 'two nation theory'3 (G.Allana (ed), 1967, Pakistan Movement: Historic Documents, p-77) which purported the 1947 partition of British India and establishment of Pakistan on the basis of religious separate identity. As later events proved, they were sadly mistaken. The primacy of Islamic traditions and sentiments cast aside by the Bengalis in East Pakistan in 1971 to fight the Pakistani crackdown and later deliberately excised by the new Bangladesh government, subsequently returned as a resilient and widespread political phenomenon. This was loosely characterized as Muslim identity, different from the Bang alee nationalism which was focused on secularism, language and literature.4 The international community was familiar with 'militant' Islam but Muslim consciousness in Bangladesh was not identical to the global Islamic fundamentalism. The growing Muslim consciousness in Bangladesh was still evolving its goals, strategies and tactics. In its broadest connotation, Muslim nationalism in Bangladesh was the sentiment and spirit of 'Muslim heritage and rule in Bengal. It was also the passion of belonging which girded, the Muslims through a common monotheistic faith and a nexus of culture, values, customs, experiences, traditions, personal laws, ways of life and rituals. These were perceived as their distinctive heritage which might, in fact, be the product of coevolving forces over a history. Its basic appeal was the sense of pride, recognition, a yearning for harmony and a mystique which made them 'feel good' and secure against internal constraints and external threats. However, the real arena of dispute between Islamic identity and Bang alee nationalism was its domestic politics. After the breakup of Pakistan, it was an uphill slog for the Islamists to regroup and reassert themselves as a viable political force. The primary objective of this paper is to examine the cultural and political dynamics of Islam and Muslim consciousness in Bangladesh and their confrontation with the secularists and the Bang alee nationalists and try to give an analysis on the nationalism trends of Bangladesh.
\end{abstract}

Keyword: Muslim identity, Bengali Nationalism, Bangladesh

\section{Introduction}

Bangladesh becomes an independent and sovereign state in 1971 from Pakistan. After a decisive battle, people of Bangladesh got a separate territory and also a separate national identity. Then it is to be noted that what will be the national identity of the people of this newly independent country? It becomes the talk of the issue just after independence war of 1971, when government of Bangladesh adopt parliamentary Democracy, Socialism, Secularism, and Nationalism in its constitution of 1972 as fundamental principles according to the Indian model. (Jahan,Rounaq,February 1973) Through the fourth amendment of the constitution of Bangladesh largely brought changes in the system of government and adopted one party system instead of parliamentary democratic system. In a relatively short span of three years following the birth of the country, the ruling elites in Bangladesh first adopted and later rejected parliamentary democracy as its model of government and politics. Also the ruling elites did not have sufficient empathy for liberal constitutional

\footnotetext{
${ }^{1}$ - By the partition of Indian sub-continent from British colonial rule at 1947, two separate states was born named Pakistan and India. East Pakistan was the eastern part of Pakistan till the Independent war of Bangladesh at 1971.

2 - That means Muslims are separate tribe from others tribe of this region. In early twentieth century Muslims of India thinks that on the basis of religion they are a separate nation from others nations of this sub -continent.

3 - It's also known as Pakistan movement. Muslims and Hindus are two separate nations in Indian perspective. So they treated as separate nation and they have right to self-determination and separate homeland.

4 - Although Bengali and Bang alee are used synonymously, the passionate nationalists in Bangladesh preferred to be called Bang alee. 
democracies and they grossly violated the rules of the game. (UPL, Dhaka, 1980) After major change in the political power of Bangladesh fundamental principles of the constitution of Bangladesh were also radically changed. (Akbar $\mathrm{S}$ Ahmed,) As a result, nationality and national identity of the people of Bangladesh also changed. The principles of absolute trust and faith in the Almighty Allah, nationalism, democracy and socialism meaning economic and social justice were adopted in place of prior fundamental principles taken in the constitution of $1972 .{ }^{5}$ By another amendment Islam becomes the state religion of Bangladesh.6 (Akbar S.Ahmed, 1992 Postmodernism and Islam) For, long forty years of the independence people of Bangladesh fall in this controversial situation either they are Bangladeshi or Bang alee. ${ }^{7}$ What is happening about the identity of the Muslims of Bangladesh? It is said that Bangladeshi nationalism derived from its predominant Muslim heritage and tradition.

\section{Nationalism in Bangladesh}

Nationalism in Bangladesh is not a new matter; it's a concerned agenda from the period of British-India. Our national identity also depends on this background. We are either Muslims or Bang alee or Bangladeshi, this question is around us for a long time. So before discussing the nationalism in Bangladesh, we need to highlight the nationalism trends in Bengal from the British colonial period in order to have a clear understanding about this historical event.

Firsstly-The sense of separate nationality (as a Bang alee) is raised into the mind of this region in the pre -British period. In this time a mixed culture between Hindu and Muslim is created in Bengal by rising Hindu 'sohojia' religious faith, the open mind of the Muslim Sufis and their preaching of brotherhood beyond religion and region and through the patronization of Bengal language and literature by the Muslim rulers and Sultans. Secondly- Development of separate Muslim nationalism in the last era of $19^{\text {th }}$ Century offers another view. In the last era of $19^{\text {th }}$ century, Muslim middle class has raised their misconception with the Hindus of Bengal. Muslims of Bengal feel their backwardness in every sector like Literature, Education, Politics, and Culture. So, in this time, Muslims of Bengal think a separate identity of them to develop their position in all sectors. For these reasons, Muslims of Bengal develop Muslim Nationalism instead of Bengal Nationalism. Based on separate nationalism in 1947, Bengal was divided for the second time. Thirdly- the rise of Bang alee Nationalism after the separation of 1947 creates a special world in the mind of East-Pakistani people. Policies of Pakistani rulers were almost made against the East-Pakistan (East- Bengal) and East-Bengal's people started to raise this separate thinking. And Liberation war of 1971 against the Pakistani rulers makes a strong link to this separate National Identity.

\section{What is Nationalism?}

Nationalism stands for a uniform which makes people united under a roof. Bearing this uniform, a nation may introduce itself as an independent and fundamental nation throughout the world having a separate identity. Nationalism involves a strong identification of a group of individuals with a political entity defined in national terms, i.e. a nation. It is the belief that a nation has a right to statehood. ${ }^{8}$ (Smith, Anthony, D, 1993) Although there are various definitions for what constitutes a nation, which leads to several different stands of nationalism. It can be a belief that citizenship in a state should be limited to one ethnic, cultural or identity group, or that multi-nationality in a single state should necessarily comprise the right to express and exercise national identity even by minorities. ${ }^{9}$ (Kymlicka,Will, 1995)It can also include the belief that the state is of primary importance, or the belief that one state is naturally superior to all other states. ${ }^{10}$ (Ernest Gellner and John Breuilly, 1993) It is used to describe a movement to establish or protect a homeland (usually an

\footnotetext{
5 - The second proclamation (fifth amendment) order no-IV of 1978

6 - The Eighth Amendment Act was passed on 7 June 1988

7 - Now government of Bangladesh decided to re-establish the constitution of 1972 and also Fifth Amendment was declared unlawful by the Supreme Court of Bangladesh. Recently Bangladesh government adopts fifteenth amendment of the constitution of Bangladesh and in this constitution they change the national identity of the people of Bangladesh. Now the people of Bangladesh are Bangalee in their national identity

8 - for details see "National Identity" by Anthony Smith

9 - See "Multicultural Citizenship: A Liberal Theory of Minority Rights" by William Kymlicka

10 - For details see "National Identity" by Anthony Smith. Ernest Gellner and John Breuilly says in their Books titled "Nation and Nationalism'- "In brief, nationalism is a theory of political legitimacy, which requires that ethnic boundaries should not cut across political ones." page- 1 
autonomous state) for an ethnic group. In some cases the identification of a national culture is combined with a negative view of other races or cultures. ${ }^{11}$ (Thomas Blank and Peter Schmidt, 2003) Conversely, nationalism might be portrayed as collective identities towards imagined communities 12 which are not naturally expressed in language, race or religion but rather socially constructed ${ }^{13}$ by the very individuals that belong to a given nation. (Anderson, Benidict, 1991) Nationalism is sometimes reactionary, calling for a return to a national past, and sometimes for the expulsion of foreigners. Other forms of nationalism are revolutionary, calling for the establishment of an independent state as a homeland for an ethnic underclass. Nationalism emphasizes collective identity - a 'people' must be autonomous, united, and express a single national culture.( John and Smith, Anthony D, 1994) Integral nationalism ${ }^{14}$ is a belief that a nation is an organic unit, with a social hierarchy, co-operation between the different social classes and common political goals. However, liberal nationalists stress individualism as an important part of their own national identity. (Anthony D Smith, 2002)National flags, national anthems, and other symbols of national identity are often considered sacred, as if they were religious than political symbols. Deep emotions are aroused. (Billig, Micheal, 1995)

\section{Bangalee Nationalism}

Bengali nationalism is the political expression of ethno-national consciousness of the Bengali people, who inhabit the ethno-linguistic region of Bengal. ${ }^{15}$ The region's territory is divided between Bangladesh and the Indian state of West Bengal. Arising in the 19th century with the Bengal Renaissance ${ }^{16}$ and the Indian independence movement ${ }^{17}$ it would be the central influence in the Bengali Language Movement ${ }^{18}$, the Bangladesh Liberation War and the creation of

${ }^{11}$ - For more discussion see -National Identity in a United Germany: Nationalism or Patriotism? An Empirical Test with Representative Data, in Political Psychology, by Thomas Blank and Peter Schmidt Vol. 24, No. 2.

12 - Imagined communities are a concept coined by Benedict Anderson. He believes that a nation is a community socially constructed, imagined by the people who perceive themselves as part of that group. Anderson's book, Imagined Communities, in which he explains the concept in depth, was published in 1983.

13 - Social constructions is a sociological theory of knowledge that considers how social phenomena or objects of consciousness develop in social contexts. A social construct is a concept or practice that is the construct of a particular group. For further reading see this linkhttp://as.nyu.edu/docs//O/1153/socialconstruction.pdf

14 - Integral nationalism is one of five types of defined by Carlton Hayes in his book The Historical Evolution of Modern Nationalism. More recently, Peter Alter discussed integral nationalism in his book "Nationalism", along with its opposite, Risorgimento nationalism. Whereas Risorgimento nationalism applies to a nation seeking to establish a state (for example, Greece, Italy, Germany, Poland and Serbia in the 17th century), integral nationalism results after a nation has achieved independence and has established a state. Nazi Germany and fascist Italy, according to Alter, were examples of integral nationalism. Some of the qualities that characterize integral nationalism are anti-individualism, statist, radical extremism, right-wing ideology, and aggressive-expansionist militarism.

15 -Bengal is a historical and geographical region in the northeast region of the Indian Subcontinent at the apex of the Bay of Bengal. Today, it is mainly divided between the sovereign land of People's Republic of Bangladesh previously East Bengal/East Pakistan and the Indian state of West Bengal, although some regions of the previous kingdoms of Bengal (during local monarchical regimes and British rule) are now part of the neighboring Indian states of Bihar, Jharkhand, Assam, Tripura and Orissa. The majority of Bengal is inhabited by Bengali people who speak the Bengali language.

16 -The Bengal Renaissance refers to a social reform movement during the nineteenth and early twentieth century's in the region of Bengal during the period of British rule. The Bengal renaissance can be said to have started with Raja Ram Mohan Roy(1775-1833) and ended with Rabindranath Tagore(1861-1941), although there have been many stalwarts thereafter embodying particular aspects of the unique intellectual and creative output. Nineteenth century Bengal was a unique blend of religious and social reformers, scholars, literary giants, journalists, patriotic orators and scientists, all merging to form the image of a renaissance, and marked the transition from the 'medieval' to the 'modern'.

17-The term Indian independence movement encompasses a wide spectrum of political organisations, philosophies, and movements which had the common aim of ending first British East India Company rule, and then British Imperial Authority, in parts of South Asia. The independence movement saw various national and regional campaigns, agitations and efforts of both nonviolent and militant philosophy.

18 -The Bengali Language Movement, also known as the Language Movement was a political effort in Bangladesh (then known as East Pakistan), advocating the recognition of the Bengali Language as an official language of Pakistan. Such recognition would allow Bengali to be used in government affairs. 
Bangladesh in $1971^{19}$.

Bengali nationalism is rooted in the expression of pride in the history and cultural heritage of Bengal. In it, what is described as the Bengal Renaissance, the introduction of Western culture, science and education led to a major transformation and development of Bengali society? Bengal became a centre of modern culture, intellectual and scientific activities, politics and education under British Raj20. The first social and religious reform movements such as the Brahmo Samaj21 and Ramakrisna Mission ${ }^{22}$ arose in Bengal, as did national leaders and reformers such as Raja Ram Mohan Roy,Ramakrisna Paramansa and Swami Vivekananda. Bengali literature, poetry, religion, science and philosophy underwent a massive expansion with the works of Bankim Chandra Chatterjee,Devendranath Tagore,Michael Madhusudan Dutt,Sharat Chandra Chattopadhyay,Ravindranath Tagore,Satyendra Nath Bose,Jagdish Chandra Bose and kazi Nazrul Islam. TheYoung Bengal, Jugantar ${ }^{23}$ movements and newspapers likeAmrita Bazar Patrika led the intellectual development of India. The Calcutta-based Indian National Association and the British Indian Association were the earliest political organizations in India.

The first Bengali nationalist agitation emerged over the 1905 Partition of Bengal24 by British authorities. Although the partition was supported by Bengali Muslims, a large number of Bengalis protested the partition and participated in Civil disobedience campaigns such as the 'Swadeshi movement'25 and mass boycott of European goods. Seeking a united Bengal and rejecting British hegemony, Bengalis also spearheaded an emerging revolutionary movement, which assumed a central role in the national independence struggle. Bengal became a strong base of the Indian struggle for independence, giving rise to national political leaders such as Bipin Chandra Pal,Khwaja Salimullah,Chittaranjan Das,Maulana Azad,Subhash Chandra Bose, his brother Sarat Chandra Bose,Syama Prasad Mookerjee,A.K.Fazlul Huq,Huseyn Shaheed Suhrawardy the latter two would become important leaders of the Pakistan movement. ${ }^{26}$

While the conflicts between East and West Pakistan over economy and language were well known, the Awami Leaguers anti the secessionists were overtaken by the sudden outburst of a civil war, quick Indian involvement and the rapid collapse of Pakistan military. Sheikh Mujibur Rahman (also known as Mujib/Bangabhandhu) wanted maximum autonomy for East Pakistan under his celebrated six-point demands but there was no conclusive evidence that he desired a complete secession. However, General Yahya Khan's refusal to transfer power to the newly elected Awami League majority in the national legislature catapulted East Pakistan into a sudden anti terrible civil war. Consequently, the political landscape drastically changed in 1971 and neither the leaders nor the people had enough time to deliberate upon Bangladesh nationalism and delineate its roots anti future implications.

Partly under Indian prodding, accelerated by ebullience and driven by the 'affinity-similarity' emotions for a common Bengali heritage, the political leaders, students, intellectuals and civilians, thrown into exile by wanton repression, defined

19 -The Bangladesh Liberation War was an armed conflict pitting East Pakistan and India against West Pakistan. The war resulted in the secession of East Pakistan, which became the independent nation of Bangladesh.

${ }^{20}$-British Raj was the British rule in the Indian subcontinent between 1858 and 1947; The term can also refer to the period of dominion.

${ }^{21}$-Brahmo Samaj is one of the most influential religious movements responsible for the making of modernIndia. It was conceived at Kolkata in 1830 by Dwarkanath Tagore and Ram Mohan Roy as reformation of the prevailing Brahmanism of the time (specifically kulin practices) and began the Bengal Renaissance of the 19th century pioneering all religious, social and educational advance of the Hindu community in the 19 th century.

${ }^{22}$-The Ramakrishna Mission is a philanthropic, volunteer organization founded by Ramakrishna's chief disciple Swami Vivekananda on May 1, 1897. The Mission conducts extensive work in health care, disaster relief, rural management, tribal welfare, elementary and higher education and culture.

${ }^{23}$-Jugantar was one of the two main secret revolutionary trends operating in Bengal for Indian Independence.

24 -The Partition of Bengal in 1905 was made on October 16 by then Viceroy of India, Lord Curzon. Partition was promoted for administrative regions; Bengal was as large as France but with a significantly larger population. The eastern region was thought to be neglected and under-governed. By splitting the province, an improved administration could be established in the east where, subsequently, the population would benefit from new schools and employment opportunities. However, other motives lurked behind the partition plan.

25 -The Swadeshi movement was an economic strategy aimed at removing the British Empire from power and improving economic conditions in India by following the principles of swadeshi (self-sufficiency), which had some success. Strategies of the Swadeshi movement involved boycotting British products and the revival of domestic-made products and production techniques. Swadeshi Movement began with the partition of Bengal by the Viceroy of India, Lord Curzon, 1905 and continued up to 1908. It was the most successful of the pre-Gandhian movements.

${ }^{26}$ - The Pakistan Movement refers to the historical movement to have AN independent Muslim state named Pakistan created from the separation of the north-western region of the Indian subcontinent, partitioned within or outside the British Indian Empire. 
their nationalism as a desire to quickly extricate themselves from the military brutalities. There was no well thought out paradigm of collective consciousness, the symbols and national ethos for the emerging nation. While Mujib in Pakistani jail, the tower of political leadership was absent in Calcutta where the future ideological map of the new nation was drawn. The polemics of the exiled leaders, the noises of independence war and radicalism of the freedom fighters were more a language of vengeance, fantasy and escape. Much of what they did were designed to tap deep into the Bengali resentment and rejection of Pakistan, lock, stock and barrel including the Muslim identity which midwife the creation of a separate Muslim state in 1947.

In the wake of military suppression, brutalities, fire and hate, a small group of secular and radical leaders, intellectuals and students selected the symbolism of Bangladesh nationalism. Even in Calcutta, there were reservations about the Rabindra Nath Tagore's poem (reportedly composed in the wake of protests against the 1905 partition of Bengal) selected as the Bangladesh national song. To the more rabid critics, that national anthem reflected neither the culture nor the traditions of Bangladesh, a predominantly Muslim nation though it became separated from Pakistan.

After independence, Bangalee nationalism in 1972-73, regrettably though, took a xenophobic and fascist turn while elements of the Awami League, the Mukti Bahini (freedom fighters) and other numerous forces let themselves lose to abduct, extort and kill the so-called Razakars, Al-Badars, the Biharis, the pro-Pakistanis and the like. Many people suffered horrendous punishments for their deeply cherished personal political beliefs without ever committing a crime.

Those who believed in united Pakistan had the right to do so until former East Pakistan became independent Bangladesh. Their beliefs in 1971 could be debated for 'political incorrectness' but it was a serious civil rights violation to persecute and punish people for their views. Of course, those who were guilty of any cognizable crimes during the liberation war in 1971 could have been punished through the due process of law.

The violence and widespread breach of civil liberties perpetrated on the alleged 'collaborators' of the former Pakistan regime were largely underreported in the western media. In 1972, the Holiday, a respected political weekly, wrote in disgust that the new nation had 65 million 'collaborators' (referring to the majority of Bengali speaking people who did not flee to India while it was unofficially estimated that nearly 10 million crossed over to India). The real motivations behind the vigilante justice and total disregard for the law and order were not difficult to find. In many cases, nationalistic fervor and overt patriotism was only a facade for grabbing properties and jobs of the so called anti-national and anti-liberation elements. Teachers, civil servants, business executives, industrialists, traders and businesspeople were the special targets that were forced out of their jobs, evicted from their houses and businesses. In their places, certain Bangladeshis, backed by government were the real beneficiaries.

In the name of Bangalee nationalism, the Awami League government tried to erase the symbols of Muslim history, culture and politics in the Indian sub-continent which ironically made Bangladesh possible in 1971. Nationalism, secularism, democracy and socialism collectively called Mujibism (named after Mujib) were the new ideological brew and Joi Bangla (Victory to Bengal) was the fresh patriotic call in Bangladesh. The government went after such petty pursuits as changing the names of streets and educational institutions with a demonstrated vengeance and a total disregard to the political sensibilities of the people.

It was customary to initiate public functions with a recitation from the Qu'ran which the new Bangladesh government eliminated in 1972. Friday was the weekly holiday during Pakistan era which was later changed to Sunday. The Awami League government, the student groups and their intellectual cohorts made no distinction between denouncing the Pakistan military and humiliating the deep emotional bond with the Muslim cultural heritage and tradition of the vast majority in the country. Another drastic step was to ban all political parties and groups with any Islamic stance. The process of secularization and the banishment of Islam from public life in the new nation tantamount to a cultural exile become troublesome for many Bangladeshi Muslims in their own country. Contrary to the constitutional guarantee to 'all faiths and 'neutrality' to all religions, the new Bangladeshi government demonstrated an intense hostility towards Islam as a political and cultural symbol.

Bangladesh was very much a divided country in the early 1970's while the extended families were drawn apart by the trauma of a civil war and struggle for secession and independence from united Pakistan. Those who fought for an independent Bangladesh and those who opposed it or wanted to remain loyal to the idea of a united Muslim homeland in the subcontinent often came from the same family, same village and same establishment. For several years, it was a society where brothers, sisters, cousins, colleagues, relatives and friends were pitted against each other. The new political elites in the early years of Bangladesh suffered from political myopia who failed to appreciate the need for a broader consensus and national unity through a pre-concept of the cultural inheritances.

Enmeshed in rhetoric and symbols, there was a serious confusion between Bangladesh nationalism and Bang alee nationalism. If language be the sole root of nationalism, why didn't West Bengal join the separatist struggle of former East 
Pakistan? That was more than a rhetorical issue. One could argue that in 1971, it was politically and strategically unrealistic for West Bengal to join the Bangladesh struggle for creating a bigger united Bengal. But there was no overt gesture for a united Bengal as a free, independent and sovereign nation while isolated intellectuals and fringe groups had toyed with such ideas.

Neither the new political leaders nor the intellectual elites tried to work out a compromise between the Muslim heritage and the Bang alee nationalism. Islam, Muslim identity and collaboration with the Pakistan military savageries were unfortunately lumped together with obvious political purposes. After the assassination of Mujib and the bloody overthrow of government in 1975, the identity questions came to the front. The 1975 coup leaders in a haste declared Bangladesh an Islamic state which was later hushed by new president Khandker Mushtaque Ahmed ostensibly for the fear of Indian provocation. However, it was President Ziaur Rahman (popularly known as Zia) who tried to draw a distinction between Bangladesh nationalism and Bang alee nationalism. He amended the constitution to describe the citizens of Bangladesh as Bangladeshi (not Bang alee). The rationale was that Bangladeshi was Bengali speaking but they were the citizens of an independent and sovereign nation-state while the Bengali in West Bengal was the citizens of India. In the wake of rising Islamic sentiments, being the chagrin of the secularists and minorities, Zia restored the observance of most Islamic rituals in the state business (which was resented by the Hindus and other religious minorities) while he refused to declare Bangladesh an Islamic state. He argued that Bangladesh, with a 90\% Muslim population, had been a de facto Islamic state. This distinction of Bangladesh nationalism from a more generalized Bang alee nationalism of all Bengali speaking people was subtle but politically significant for spelling out the identity of the new nation. In the meantime, the Islamic parties were legalized by the Zia government.

\section{Bangladeshi Nationalism}

Bangladeshi nationalism is a political ideology that glorifies and promotes the citizens of the People's Republic of Bangladesh as a distinctive cultural and political nation. In contrast with its rival Bengali nationalism, the ideology emphasizes a clear distinction amongst the Bengali people that essentially Bangladeshi citizens are different from their linguistic and cultural counterparts in the Indian state of West Bengal which borders Bangladesh. The term also has religious significance and was initially developed by Bangladesh's first military regime in order to politically counter the ideology of the Awami League party ${ }^{27}$ that professed Bengali nationalism and led the Bangladesh Liberation War on the basis of the establishment of a sovereign homeland for the Bengali people. As opposed to the secular Bengali nationalism, Bangladeshi nationalism stresses the ethnic and Islamic consciousness of the people of Bangladesh, where $89 \%$ of the populations are Bengali Muslims.

Throughout the late 1970s and then in the 1980s, the concept of Bangladeshi nationalism evolved into the principal ideology for a large section of Bangladesh's political and military establishment. It had been fiercely promoted by President Ziaur Rahman ${ }^{28}$ and his formation of the Bangladesh Nationalist Party, now one of two major political parties of the country, had centered on the development of Bangladeshi nationalism. Politically, the concept is today advocated by the center-right and rightist political parties in Bangladesh led by Zia's Bangladesh Nationalist Party.

The historic region of Bengal has been renowned for its rich cultural and linguistic heritage. The territorial unity and population growth of the region ran parallel with the development of the Bengali language under the patronage of the Turk-Afghan rulers of the Shah-i-Bangla, or Sultanate of Bengal. Besides developing Bengali, their next most outstanding contribution to the growth of Bengali identity was evolving of a politics based on Hindu-Muslim partnership and cooperation. The trend was further strengthened under the Mughal Empire. During the reign of the Nawabs of Bengal29 in the eighteenth century, which was a remarkable example of Hindu-Muslim unity, Bengal showed all the marks of the

27 -The Bangladesh Awami League, commonly known as the Awami League, is the mainstream center-left, secular political party in Bangladesh. It is also currently the governing party after winning the2008 Parliamentary election in Bangladesh.

28 - Ziaur Rahman (January 19, 1936 - May 30, 1981) was a Bangladeshi politician and general, who read the declaration of Independence of Bangladesh on March 26, 1971 on behalf of Sheikh Mujibur Rahman. He later became the seventh President of Bangladesh from 1977 until 1981. He founded the Bangladesh Nationalist Party (BNP), one of the two largest political parties in the country. He is popularly known as Shaheed President Zia, meaning martyred Zia, in reference to his 1981 assassination.

29 -The Nawabs of Bengal were the hereditary nazims or subadars (provincial governors) of the subah (province) of Bengal during the Mughal rule and the de-facto rulers of the province. 
progressive growth towards the formation of a nationstate ${ }^{30}$ ( Alfred Michael Boll,2007) in the European model taking shape after the fall of the Holy Roman Empire. With the defeat of Siraj-ud-Daula, the last independent Nawab of Bengal, by the British East India Company, Bengal lost its independence and its achievements during previous centuries in the fields of arts and crafts, manufactures and industries, education and administration were overturned under the impact of the colonial rule. However, gradually the British began fostering the European model of education in Bengal, the first province they captured in India. This led Bengal and especially Calcutta (present day Kolkata in West Bengal, India), the capital of British India during much of the British Raj, to be the prime centre of modern culture, intellectual and scientific activities, politics and education in the Subcontinent. What is described as the Bengal Renaissance, the introduction of Western culture, science and education led to a major transformation and development of Bengali society?

However, much of the benefits of the colonial transformation had hardly touched the people of eastern Bengal who were mainly Muslims. Bengali Muslims had resented the British and their education system, especially the English language, because of the defeat of the region's independent Muslim rulers. Many Muslim zamindars were abolished and through the Permanent Settlement of 1793, the British introduced a harsh system of taxation on Bengali peasants who were mainly Muslim. With the resentment of English and the marginalization of the Muslim aristocracy, educated elite of Bengali Hindus emerged. They were seen as affluent and occupied positions in the civil service, judiciary and universities.

\section{Muslim identity and Bangladeshi Nationalism}

The yearning for Islamic identity in Bangladesh was part of a historical confrontation in Bengal interwoven with hundreds of years of Hindu-Muslim interactions driven by the cultural and political dynamics of the subcontinent. However, the intellectuals in Bangladesh and abroad in recent years endeavored to rewrite the history of the Muslims in South Asia. There has been a trend to undercut the earlier theses of Muslim separatism endorsing the two-nation theory which partitioned the Indian subcontinent in 1947.

In his study of Bengali Muslims, Rafi Ahmed contended that the "basic foundations of Muslim separatism in India rested on the assumptions which were historically incorrect.15 U.A.B. Razia Akter Banu made two leading observations in her book: (a) Bangladeshi Muslims, influenced more by secular symbols, had no identity crisis and (b) Islam lost much of its political importance in modern Bangladesh.( Rafiuddin Ahmed,1981) Sirajul Islam's (ed.) History of Bangladesh (3 volumes) also added to the controversy on the subject. ( U.A.B. 'Razia Akter Banu,1992) Since 1971 the intellectual twist was that Bengali Muslim separatism had been an orthodox Islamic contraption while there was a larger linguistically Bang alee oriented secular nationalism shared by the Hindus and Muslims.

Such studies, researches, commentaries, editorials, flourishing at the hands of scholars, journalists, writers, poets and political activists had a common characteristic: the liberals, secularists and the Bang alee nationalists marginalized the Islamic traditions of Bangladesh. The 'ties of language' had the primacy over religious and other components of cultural inheritance, according to those intellectual groups who had the upper hand in the universities, academic forums and the media. The secularists and Bangalee nationalists have been more confrontational in their treatment of the Islamic culture in Bangladesh. In many ways, the liberal belligerence to Islamic movements in Bangladesh was compared to the western fears and stereotypes routinely dumped on the so called Muslim fundamentalism. Those who believed in Islamic identity had a very different perception of Muslim cultural history in Bengal. They blamed the liberals, radicals, secularists and Bangalee nationalists for glossing over the cultural realities and demonizing the Muslims which frequently reflected the intellectual sight of their western and Indian counterparts. However, there were many Islamic writers, scholars and politicians who criticized the secularists and Bangalee nationalists for deliberately disregarding the distinctive Muslim heritage. Mohammad Azraf, a respected Islamic thinker (an author and frequent contributor to news paper articles/magazines) has championed the cause of Muslim culture in Bangladesh. The Jamaat and other Islamic groups also denounced what they described as a deliberate 'cultural subversion' by a handful of intellectuals. A retired academic who frequently wrote on Islam, Muslim culture and literature, found serious flaws with History of Bangladesh.(Sirajul Islam (Ed.),1992) In the dispute over national consciousness in Bangladesh, there were two separate schools of thought, one

30 -The nation state is a state that self-identifies as deriving its political legitimacy from serving as a sovereign entity for a nation as a sovereign territorial. The term "nation state" implies that the two geographically coincide, which distinguishes the nation state from the other types of state, which historically preceded it. The concept of a nation state is sometimes contrasted with city state. 
asserting a separate Muslim identity and the others opposing it. Both the secularist and Islamist intellectuals were deeply politicized on identity issues.

The 'cultural divide' between the religious right and the liberals in Bangladesh was not a new political phenomenon. The debate between the secularists and Islamists in Bangladesh was not an academic wrangle but an inheritance of the Muslim resistance to the Hindu cultural and political hegemony in undivided Bengal under the British. With the rise of the British Raj, the nature of government and civil society in Bengal transformed. Below the British officers, the government jobs mostly went to the growing Hindu educated middle class who were willing to cooperate with the new rulers and accept western learning. ${ }^{31}$ (S. Sajjad Husain, 1994) Farsi ceased to be the official language in the mid-19th century which rendered the old language skill useless seriously undermining the intellectual edge of the Muslim upper class.

In the new civil society which ushered in colonial Bengal, the nouveau Bengali elites were predominantly Hindus concentrated in Calcutta. The Bengali political economy, culture and literature that flourished from the middle of 19th century were essentially a Hindu domain without any noteworthy Muslim presence until much later. ${ }^{32}$ (J.H. Broomfield, Elite Conflict in a Plural Society, 1968 and A.R. Mallick, 1977) Defeated by the British and overtaken by the new Hindu middle class, the bulk of the Muslims were, to quote W.W. Hunter, the 'hewers of wood and drawers of waters'.

The Hindus and Muslims shared the same civil society and imperial authorities but their cultural lives were not identical. Calcutta, the new seat of the British colonial power also became the cultural Mecca for the educated Bengalis. The Hindu leadership in education, literature and economy soon appeared as the cultural hegemony which the Muslims resented but could not halt. In the early years of the British Raj, it was a common practice to downgrade Islam and the Muslims in India. The English writers, academics, bureaucrats and missionaries found it convenient to present a low picture of the Muslims to legitimize the British seizure of India from the remnants of the Mughal Empire.

Soon, the emerging Indian writers and scholars also followed the suit and imitated the British academic and literary traditions. In their presentation of Islam and Muslims in India, the growing (Hindu) litterateurs and scholars demonstrated a contortion, an attitude and a treatment pretty close to the intellectual tenor of the European Orientals who tended to support the rising colonialism in Asia. ${ }^{33}$ Earlier this century, Muslim separatism in Bengal was, to a great extent, ignited by the defamed presentation of the Muslims at the hands of numerous Hindu scholars and writers.

\section{Bangladesh Nationalism: An Ambivalent Quest}

The search for national identity became ambivalent while the Bangladeshis were caught between the political inheritances of two historical failures: firstly, it was 1947, a vain attempt of unifying the Hindus and Muslims of Bengal on the shared linguistic heritage; secondly, it was 1971, the failure of keeping the eastern and western wings of Pakistan on the basis of Islam, the common religion. The Hindu-Muslim Pact of 1947 failed because the Indian National Congress (including Gandhi, Nehru and most top Hindu leaders) opposed it. H.S. Suhrawardy and several other veteran Bengali Muslim leaders favored the Pact while Sarat Chandra Bose, initially supported it but later withdrew under heavy pressure from the Indian National Congress and what was then known as the Hindu press. The Bengal Pact of 1947 failed because the Hindus opposed the concept of a united and sovereign Bengal which was likely to be dominated by the Muslim majority. The Bangladeshis could not realistically look at the future possibilities of a 'Greater Bengal' entity as an extension of their passionate Bang alee nationalism.

While Islam was a strong symbol of Pakistan movement, the Bengalis in East Pakistan refused to acknowledge a religious legitimacy for a continuing military-bureaucratic regime which denied adequate political participation and economic redress for the eastern wing of the country. Ironically, once East Pakistan became independent Bangladesh, the bulk of the Muslims not only refocused their Muslim identity but also turned against India. Yet, there was no political urge for Bangladesh to be reintegrated with Pakistan. The ambiguous search for Bangladesh nationalism is caught somewhere between a secular Bangalee nationalism and a Muslim Bengal which will not be driven by Islamic orthodoxy

\footnotetext{
31 - S. Husain in his review article on History of Bangladesh (1704-1971), severely criticized the hypothesis that there had always existed a common Bengali nationalism based on language, shared by the Hindus as well as Muslims.

32 - For a social picture of the Bengali Muslims in the 1920's and 1930's, see Mahbubur Rahman, Kisu Smriti, Kisu Dhriti, Nawroz, 1987 (Bengali text). It is an autobiography of a senior civil servant who held important positions in independent Bangladesh.

${ }_{33}$ - For a classic discussion on this subject, see W.W. Hunter, The Indian Musalmans, London, 1872. In his popular Bengali fiction (in two volumes), Sei Samai, Anand Publishers, Calcutta, 1983, Sunil Gangopadhya depicted the 19th century social picture in Calcutta. Also A.R.Mallick,British Policy and the Muslims in Bengal (1757-1856), Dacca, 1977. 
but the aspirations and symbolism of Muslim cultures and values will be adequately recognized and reflected in public life.

After the 1975 coup, the earlier secular and liberal hostility of the government was gradually softened while the new military and political leaders perceived Islam and Muslim identity as an effective tool to neutralize West Bengal's cultural preponderance in Bangladesh political life. Actually, the thaw started during the later part of the Mujib era (197275) when Bangladesh government wanted the diplomatic recognition and economic assistance from the oil rich Arab countries.( Syed Anwar Husain,1990) Even Maulana Bhasani, the octogenarian radical leader led the rising tide of antiIndia campaign and came in support of the growing Muslim consciousness for Bangladesh.( M.Rashiduzzaman,1977)

Both Zia and Ershad exploited the growing Muslim identity for furthering their respective political agendas from mid-1970. While Zia's Islamic policies were ambivalent, General Ershad saw a greater potential in utilizing the Islamic twist after his coup in March 1982. However, all the Islamic forces in Bangladesh did not uniformly respond to Ershad's overtures. For example, the Jamaat-i-Islam continued to support the democratic alliance opposed to the Ershad regime. However, Ershad was successful in enticing leaders of some smaller Islamic groups in supporting him.

When the Ershad regime fell, for a while it looked like a takeover by the Awami League which was conspicuous in the media and prominent in the care-taker government. The 1991 electoral verdict was a disaster to the Awami League although it lost the election by a narrow margin. When the election results were out, the Awami League leaders blamed the religious right as one of the critical forces behind their electoral defeat. Although the Islamic groups did not win the election, the Jamaat had won 20 parliamentary seats. The Jamaat itself had a steady constituency of supporters but did not have a wider base because it represented a possible rule by the Islamic fundamentalists which many Bangladeshis disliked. At the early phase of the 1991 electoral campaign, democracy, secularism, economy, poverty etc. gained limelight. In the last phase of the campaign, the political tone had changed drastically. The Awami League was painted as the 'Indian B-Team' (euphemism for the Awami League's perceived subservience to India), 'anti-Muslim' and 'anti-Islam' etc. Many right wing supporters switched their votes to the BNP, the only viable choice to keep the Awami League out of power.

Actually, the Awami League was ineffective in defending its credibility against the ideological questions which were exploited not only by the Muslim nationalists, Islamic fundamentalists but also by the BNP and other moderate groups. Both the Bangladesh Nationalist Party (BNP) and the Jatiya Party attacked the Awami League on the confusion of Bang alee nationalism while there was no other serious difference between the main contending parties. Even Joi Bangla, the Awami League symbol of mobilization came under fire. Clearly, the Awami League contested the 1991 election on secularism and Bang alee nationalism which they lost but the inchoate ideology continued to torment the nation.

There was no strong Islamic leader (except the Jamaat) against whom Awami League chief Hasina could launch a counterattack. It was a shadowy but a pervasive whispering campaign that undercut the Awami League in the 1991 election. No other issue - not Ershad, not the rampant corruption, not even democracy came close to that murmuring offensive against the Awami League. But the electorate did not give the BNP a decisive victory either. However, Khaleda Zia became the prime minister through a deal with the Jamaat which agreed to support the new government but did not claim any cabinet position.

Later, the wrath of the Awami League against the Islamists was unleashed by a vigorous campaign against Ghulam Azam, ${ }^{34}$ leader of the Jamaat-i-Islam who was alleged to have collaborated with the Pakistan army in 1971 and whose party was outlawed by Mujib until Zia lifted the ban on the right wing Islamic groups. When he returned to Bangladesh in the mid-1970, he became a de facto leader of his party and emerged as a power broker after the 1991 election. Under the pressure of the Awami League and a coalition of secular and liberal groups, Ghulam Azam was sent to jail for his technical violation of a law which prohibited the opera-tion of a political party without a valid Bangladesh citizenship.

The Ghulam Azam issue also transformed the old identity dispute into a new national dilemma. While he languished in jail, there were protests and counter-protests both supporting and opposing the fundamentalist leaders claim for Bangladesh citizenship. A coalition of the secular nationalists, liberals, intellectuals, students and politicians called Nirmul Committee orchestrated an anti-Ghulam Azam campaign which transformed into a daily ritual of protests, demonstrations and strikes in Dacca in 1992 and 1993.

There was a backlash of its campaign which softened the public attitude towards the Jamaat leader. Evidently to elicit public sympathy, the Jamaat distributed video tapes showing the arrest of its leader by the police. The anti-Ghulam

\footnotetext{
34. Formar ameer of Bangladesh Jammat-e- Islami.
} 
Azam campaign was more organized and backed by the Awami League, liberal Bangalee nationalists, the secularists, certain student and intellectual groups and the radicals. On the other hand, the public sympathy for the fundamentalist leader was more subliminal felt at the informal groups, family dinners, schools, mosques and social gatherings. The cacophony of national identity dispute was dramatized by a divided judgment of the high court, one judge supporting Ghulam Azam's citizenship while the other judge dissented. Later in 1993, the Bangladesh High Court restored Ghulam Azam's citizenship and his detention was held illegal. (Craig Baxter and Syedur Rahman, 1991) The Supreme Court also upheld the High Court's decision.

\section{Conclusion}

Muslims and Hindus in Bangladesh, India and Pakistan were similar people but they found enough differences amongst themselves to divide British India into two separate nations, along religious lines, after a prolonged communal violence claiming a toll of nearly one million lives. Neither in India nor in Bangladesh, had communalism withered away since 1971, for which there was no objective explanation. While Islam and Muslim nationalism tried to reassert itself in Bangladesh, the Hindu religious parties made unprecedented political gains in India. Taking a leaf from Freud, Francis Fukuyama called it a manifestation of narcissism exaggerating minor differences among the same kind of people which eventually snowballed into a desperate search for identity. ${ }^{35}$ Those observations had some conceptual relevance to the Muslim nationalism in Bangladesh but not quite so.

In the light of our analysis, Islam and Muslim roots were a 'pre-existing' condition in Bangladesh which recently gained a fresh impetus. It was a pre-Bangladesh, pre-Pakistan and pre-British Raj consciousness and symbol, not always consistent, crystallized over hundreds of years and endured through the vicissitudes of history. The pre-British Bengal was not a 'melting pot' but more like a 'salad bowl' where the Hindu-Muslim 'ingredients' retained their respective identities albeit mellowed by common imperial authorities. Early in the 1920's, a Muslim member of the British Indian central legislature (representing a constituency in Bengal) said that the Hindus and Muslims were like the two big banyan trees standing side by side whose boughs and leaves at the top intermingled but their two trunks stood separate from each other. That metaphor of the two banyan trees standing apart had an important bearing on the Muslim awareness and the Hindu-Muslim relations in Bangladesh and other parts of South Asia. As long as it wanted to continue as a separate state without being subsumed in some other political entity, Bangladesh could not relinquish its Muslim identity as the dominant cultural glue of its nationalism.

Not only in the British period but also in present, Identity and nationalism were a discussed matter of Bangladesh. So, it needs time to settle this issue in Bangladesh. Because the political trends of this country not support any kind of settlement in the various national issues from liberation to till now. So, time will fix what will happen in future about the nationalism and identity issue of the people of Bangladesh.

\section{References}

Akbar S.Ahmed,(1992) Postmodernism and Islam, London, Routledge publishing house, Also John L. Esposito,(1992), The Islamic Threat: Myth or Reality,London, Oxford University press.

Allana, Ghulam Ali, Pakistan Movement: Historic Documents,Karachi,University of Karachi; 1967

Anderson Benedict (1991), Imagined Communities: Reflections on the Origin and Spread of Nationalism, New York, Verso. pp. 37-46.

Anthony D Smith,(2002) Nationalism, p.17-20.

Also A.R. Mallick, British Policy and the Muslims in Bengal (1757-1856), Dacca, 1977.

A.R.Mallick, Ibid.

Alfred Michael Boll (2007). Multiple nationality and international law. Martinus Nijhoff Publishers. p. 67. ISBN9789004148383. Retrieved 25 November 2010.

Agami Prokashani Dhaka,(1994), Humayun Azad Shakhatkar, Agami Prakashani, Dhaka, (Bengali text).

Billig, Michael (1995).Bengal Nationalism, London.

Craig Baxter and Syedur Rahman,(1991) "Bangladesh Votes, 1991", Asian Survey,vol-12, August, 1991.

Edward Said, Orientalism, Vintage, New York, 1979.

Elliot Tepper and Glen A. Hayes, Bengal and Bangladesh: Politics and Culture on the Golden Delta, Michigan State University.

Francis Fukuyama, "The War of All against All", The New York Times Book Review, April 10, 1994, a review of Blood and Belonging: Journey into the New Nationalism by Michael Ignatieff, Farrar, Straus and Giroux, 1994. 
Hutchinson, John and Smith, Anthony D, ed (1994), Nationalism, Oxford Readers, Oxford, Oxford University Press. pp. 4-5.

Jahan,Rounaq,professor,(1973),Bangladesh in 1972: Nation building in a new state, Bangladesh Politics(A collaction of Articles) UPL,Dhaka, 1980

Jahan, Rounaq,Proffessor,Bangladesh: Constitutional experiment in the aftermath of liberation, published in "Bangladesh politics: problems and issues, UPL, Dhaka, 1980.

James J. Novak, (1993), Bangladesh: Reflections on the Water, Indiana University Press, Indiana State, Bloomington, U.S.A.

J.H. Broomfield, Elite Conflict in a Plural Society: Twentieth Century, Bengal, Berkeley, 1968.

Kymlicka, Will, (1995), Multicultural Citizenship: A Liberal Theory of Minority Rights. Oxford, Oxford University Press. Page- 16.

M.Rashiduzzaman,(1970), "The Awami League in the Political Development of Pakistan," Asian Survey;vol-10,No-7, July, 1970, pages(574-587).

Mahbubur Rahman, Kisu Smriti, Kisu Dhriti, Nawroz, 1987 (Bengali text).( It is an autobiography of a senior civil servant who held important positions in independent Bangladesh.)

M.Rashiduzzaman, (1977)'Changing Political Patterns in Bangladesh: Internal Constraints and External Fears", Asian Survey,vol-10, September, 1977.

Nirad C. Chowdhury, The Autobiography of an Unknown Indian, London, 1951 for examples of vilification of Muslims by some Hindu writers in India.

Nitish Sengupta ,History of the Bengali-speaking People, p 211, UBS Publishers' Distributors Pvt. Ltd. ISBN81-7476-355-4.

Rafiuddin Ahmed, (1981) The Bengali Muslims 1871-1906: A Quest for identity, Oxford,Oxford University Press, p. ix. In his book, the author did not agree with the view that the Muslims in India had a sufficiently distinctive identity.

Smith, Anthony D (1993), Ibid, Reno, University of Nevada Press. Page- 72, Ernest Gellner and John Breuilly,(1993), Nations and Nationalism, (2009), "In brief, nationalism is a theory of political legitimacy, which requires that ethnic boundaries should not cut across political ones." page- 1, Cornell University Press, 2009.

Smith, Anthony D, (1993), National Identity, Reno, University of Nevada Press, Page-71.

Sheikh Mujibur Rahman,(1966), East Pakistan Awami League Draft Manifesto, Dacca 1966.

Sirajul Islam (Ed.) (1992) History of Bangladesh (1704-1971),vol-1,political History, Asiatic Society of Bangladesh, Bangladesh.

S. Sajjad Husain,(1994) Review article on History of Bangladesh 1704-1971, The Muslim World Book Review London; Winter, 1994. S. Husain severely criticized the hypothesis that there had always existed a common Bengali nationalism based on language, shared by the Hindus as well as Muslims.

Sei Samai, Anand Publishers, Calcutta, 1983, Sunil Gangopadhya depicted the 19th century social picture in Calcutta.

Sumit Sarkar, "Calcutta and the Bengal Renaissance", in Calcutta, the Living City ed. Sukanta Chaudhuri, Vol I, p. 95.

Syed Anwar Husain,(1990) "Bangladesh and Islamic Countries 1972-73".

The second proclamation (fifth amendment) order no-IV of 1978, second schedule, page no-13, published by Ministry of Law, justice and parliamentary affairs, Bangladesh.

Thomas Blank and Peter Schmidt,(2003), National Identity in a United Germany: Nationalism or Patriotism? An Empirical Test with Representative Data, in Political Psychology, Vol. 24, No. 2.

The Bangladesh Observer, July 15, 1993.

U.A.B. 'Razia Akter Banu, (1992), Islam in Bangladesh, E.J. Brill, the Netherland, p. 175. According to that study, Islam lost much of its political importance in Bangladesh.

W.W. Hunter, The Indian Musalmans, London, 1872. In his popular Bengali fiction (in two volumes),

www.Wikipedia.com

www.Banglapedia.com 
